\title{
Gulf of Mexico Ocean Monitoring System
}

\author{
John P. Blahu, George H. Born, Norman L. Guinasso, Jr., H. James Herring*, \\ Greggr A. Jacobs, F.J. Kelly, Robert R. Leben, Robert D. Martin, Jr, \\ George L. Mellor, P. Peter Nitler, Michad E. Parke, Richard C. Patchen, \\ Kenneth Schaudt, Norman W. Scheffner, C.K. Shum, Carter Ohlmann,
}

Wilton Sturges, III, Georges L. Weatherly, Douglas Webb and Henry J. White

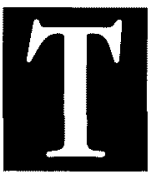

he scientific goal of the Gulf of Mexico Ocean Monitoring System was to prepare an analysis and summary of the prevailing oceanographic conditions in the Gulf of Mexico and to make it available to interested parties in near-realtime over the Internet. The results are a resource for both military and civilian users and are designed to increase public awareness of information regarding ocean conditions that is both accurate and comprehensive. The data are also a resource for other research programs in the Gulf which require oceanographic data as inputs or as boundary conditions. Finally, the resulting combination of data acquisition, analysis and model implementation represents a relocatable nowcast/forecast system, whose capabilities have been demonstrated in the Gulf, but which is equally applicable anywhere in the world.

The overall objective of this program was to demonstrate improved efficiency in the process of oceanographic research through increased cooperation and collaboration both between participants within the Ocean Monitoring System (OMS) Program and also with other research efforts in the Gulf of Mexico. The large core group of OMS participants was diverse from the outset, consisting of representatives from academia, government and industry, as encouraged by the National Oceanographic Partnership Program (NOPP) announcement. Initially each participant contacted other OMS Investigators to establish methods of data exchange and to establish where data comparisons should be made. Participants then looked beyond the OMS Program to identify others who might be interested in using our results in their work, which would eventually lead to the development of a consumer base. The most fulfilling interaction, however, was bilateral, where OMS participants established collaborative efforts with external groups that provided benefits for both. As the program proceeded, it was possible to entrain a rapidly increasing number of collaborators who either exchanged data with OMS participants, or actually carried out tasks of the research as a part of a coordinated program.

\section{Objective}

The scientific objective was to integrate a number of existing methods of data acquisition and analysis to provide initialization and input data to drive an operational nowcast/forecast numerical model capable of predicting currents and other ocean properties with 3 to 6 kilometer resolution throughout the Gulf. This objective was an application to the Gulf of Mexico of the recommendations made by Nowlin [1997] for modeling and data synthesis. New and additional sources of data were found, as described above, to maximize the effectiveness of the OMS Program tasks. Existing techniques of data analysis were refined to produce more accurate results and new types of instrumentation were explored to fill gaps in the available realtime database. An estimate of the accuracy of the various indirect measurements and the nowcast/forecast from the numerical model were reported using the realtime ground-truth data along with the results themselves wherever possible. Improved techniques of archiving, reviewing, retrieving and displaying the data were also developed to enhance the availability of the data. 


\section{Approach}

In the planning stage the OMS participants identified the areas where important data were lacking, or inaccurate, and where efforts made were most likely to produce the greatest improvement in the specification of the prevailing conditions. A series of research tasks were developed to address the most critical issues. Table 1 summarizes the original OMS tasks, indicates the results produced, the web sites where the results are presented and, finally, the OMS investigators primarily responsible for each task. The scientific goal, to provide a complete summary of the prevailing conditions in the Gulf, is beyond the resources of the OMS Program and perhaps any single effort. Therefore, from the outset attempts were made to work with other programs to gain as much leverage as possible. As a result, we have allied ourselves with as many existing programs as we felt would benefit our effort, and also actively promoted, encouraged and fostered incipient studies, such as the MMS Surface-CUrrent and Lagrangian drifter Program (SCULP).

The most ambitious collaboration, occurred through the mutual recognition that a group of scientists at Centro de Investigacion y de Educacion Superior de Ensenada (CICESE) and the Deepstar group, a consortium of oil companies working in the Gulf, were all as interested in the Yucatan Straights transport distribution problem as were the OMS Program participants. Based on lengthy discussions following a planning meeting in May 1998, an agreement was reached to collaborate on a major study to measure the distribution of transport through the Yucatan Strait and calibrate a satellite ground track to the eastern part of the Carribean Sea with a hydrographic survey to monitor the transport there with altimetry. The results will contribute to improved understanding of the behavior of the Yucatan transport. They will also facilitate the use of the altimeter measurements as nowcast/forecast boundary conditions for the numerical model. This coordinated research effort will permit the acquisition of a comprehensive and valuable data set that none of the parties to the agreement could have obtained individually. It also represents a giant step in international scientific relations and a furthering of the relations between industry, academia and government that was initiated under NOPP.

\section{Results}

The scientific results of the OMS program are shown in detail on the various web sites given in Table 1. However, results from several of the central themes of the study are outlined here. For example, the surface

\section{TOPEX SSHA Track 52 vs. Cruise Line 1 Dynamic Height}
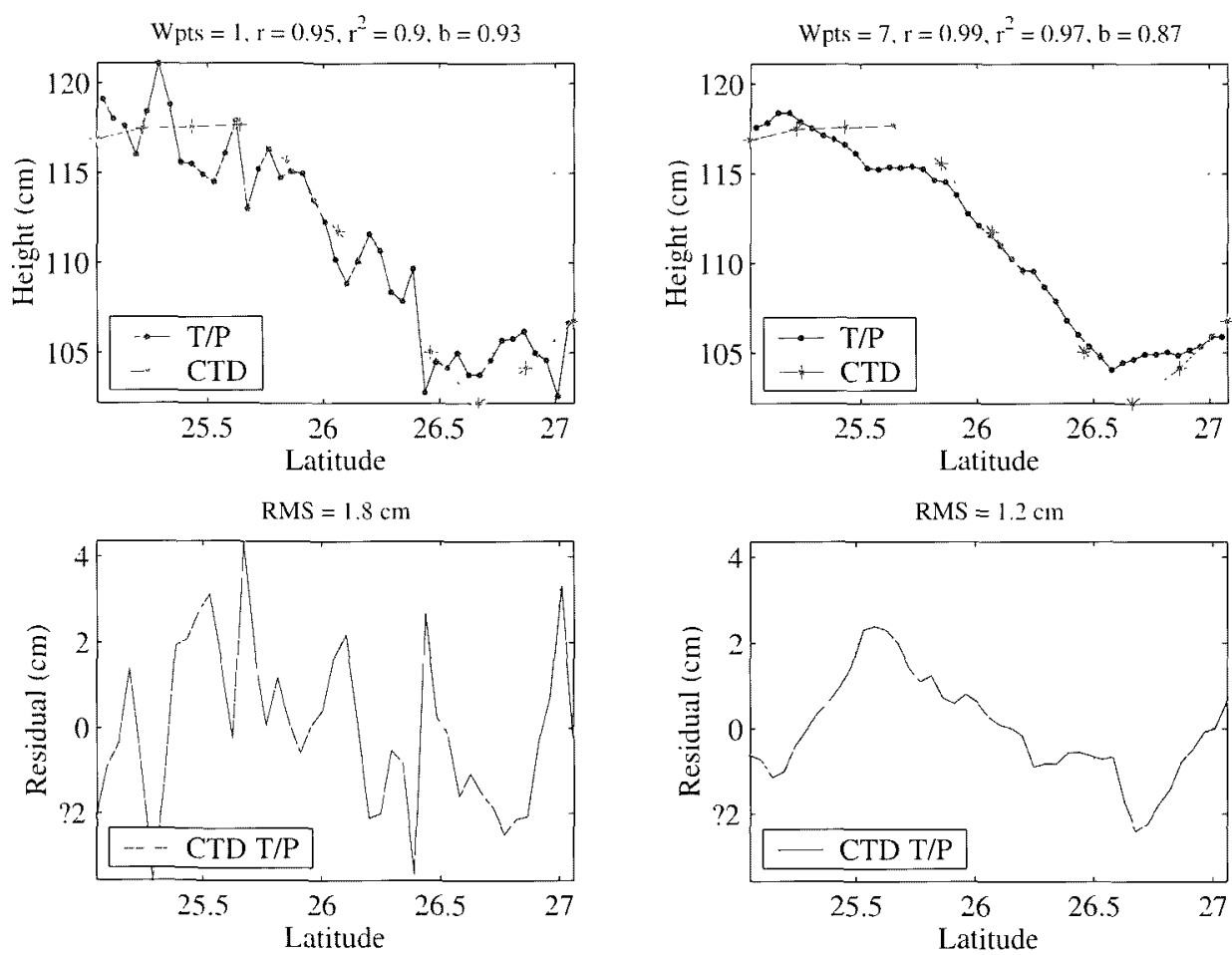

Figure 1: The upper two panels show the raw and smoothed (7 point runing awernge) sea surface height anomaly (SSHA) versus dynamic height relative to

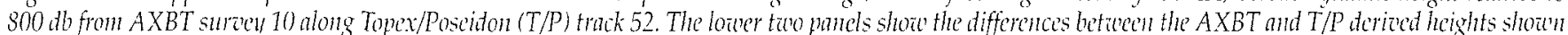
in the upper panels. The lower right pand is the synthetic estimate of the surfice height due to the "mean circulation" remowed by differencing relatioe to a 6 year T/P along-track mean, assuming a $800 \mathrm{db}$ led of no motion and no barotropic component in the mean. 


\section{Table 1. Gulf of Mexico Ocean Monitoring Research Tasks}

\begin{tabular}{|c|c|c|}
\hline Task & Result & Principal Investigator \\
\hline $\begin{array}{l}\text { Airborne surveys with aircraft expendable } \\
\text { bathythermographs (AXBT) and aircraft } \\
\text { expendable conductivity-temperature } \\
\text { depth (AXCTD) sensors }\end{array}$ & $\begin{array}{l}\text { Measurement of the vertical structure of } \\
\text { temperature and salinity along satellite } \\
\text { altimeter tracks } \\
\text { http://www.navo.navy.mil }\end{array}$ & $\begin{array}{l}\text { John P. Blaha } \\
\text { blahaj@navo.navy.mil } \\
\text { NAVOCEANO } \\
\text { Stennis Space Center }\end{array}$ \\
\hline $\begin{array}{l}\text { Operational processing of satellite altimetry } \\
\text { to produce sea surface height }\end{array}$ & $\begin{array}{l}\text { Distribution of near-realtime satellite } \\
\text { altimeter track record used to produce sea } \\
\text { surface elevation fields } \\
\text { http://www.navo.navy.mil }\end{array}$ & $\begin{array}{l}\text { John B. Blaha } \\
\text { jblaha@navo.navy.mil } \\
\text { NAVOCEANO } \\
\text { Stennis Space Center }\end{array}$ \\
\hline $\begin{array}{l}\text { Design and deployment of coastal buoy } \\
\text { system to measure surface velocities }\end{array}$ & $\begin{array}{l}\text { Measurements of surface current on satel- } \\
\text { lite tracks for comparison with geostrophic } \\
\text { velocities from satellite altimetry } \\
\text { http://www.gerg.tamu.edu/gomoms }\end{array}$ & $\begin{array}{l}\text { Norman L. Guinasso, Jr. } \\
\text { norman@gerg.tamu.edu } \\
\text { F.J. Kelly } \\
\text { www.fkelly@cvi.tamucc.edu } \\
\text { Texas A\&M University }\end{array}$ \\
\hline $\begin{array}{l}\text { Conductivity-temperature-depth (CTD) and } \\
\text { expandable bathythermography (XBT) } \\
\text { measurements }\end{array}$ & $\begin{array}{l}\text { Temperature and salinity profiles along } \\
\text { satellite ground tracks for dynamic height } \\
\text { to compare with satellite altimetry } \\
\text { http://www.gerg.tamu.edu/gomoms }\end{array}$ & $\begin{array}{l}\text { Norman L. Guinasso, Jr. } \\
\text { norman@gerg.tamu.edu } \\
\text { F.J. Kelly } \\
\text { www.fkelly@cvi.tamucc.edu } \\
\text { Texas A\&M University }\end{array}$ \\
\hline $\begin{array}{l}\text { Cruise track survey using an acoustic } \\
\text { doppler current profiler (ADCP) }\end{array}$ & $\begin{array}{l}\text { Vertical profiles of currents on satellite } \\
\text { ground tracks } \\
\text { http://www.gerg.tamu.edu/gomoms }\end{array}$ & $\begin{array}{l}\text { Norman L. Guinasso, Jr. } \\
\text { norman@gerg.tamu.edu } \\
\text { F.J. Kelly } \\
\text { www.fkelly@cvi.tamucc.edu } \\
\text { Texas A\&M University }\end{array}$ \\
\hline $\begin{array}{l}\text { Synthetic hydrographic fields from satellite } \\
\text { altimetry and surface temperature fields }\end{array}$ & $\begin{array}{l}\text { Near-real time three-dimensional fields of } \\
\text { temperature and salinity inferred from SSH } \\
\text { and SST fields } \\
\text { http://www7300.nrlssc.navy.mil/altimetry/ } \\
\text { regions/reg_gom.html }\end{array}$ & $\begin{array}{l}\text { Gregg A. Jacobs } \\
\text { jacobs@proteus.nrlscc.navy.mil } \\
\text { Naval Research Laboratory } \\
\text { Stennis Space Center }\end{array}$ \\
\hline $\begin{array}{l}\text { Satellite altimetry track error reduction } \\
\text { Geoid determination and preparation of sea } \\
\text { surface height anomaly fields }\end{array}$ & $\begin{array}{l}\text { Sea surface height anomaly fields produced } \\
\text { from optimal interpolation of T/Pand ERS } \\
\text { track data, posted on web in near-realtime } \\
\text { http://www-ccar.colorado.edu/ realtime/ } \\
\text { nopp/ccar.html }\end{array}$ & $\begin{array}{l}\text { Robert R. Leben } \\
\text { leben@jet.colorado.edu } \\
\text { George H. Born } \\
\text { georgeb@colorado.edu } \\
\text { University of Colorado - CCAR }\end{array}$ \\
\hline Monitoring of Texas Automated Buoy System & $\begin{array}{l}\text { Provide real time surface velocity data for } \\
\text { calibration of the satellite altimeter algorithm } \\
\text { http://www.gerg.tamu.edu/Tglo }\end{array}$ & $\begin{array}{l}\text { Robert D. Martin, Jr. } \\
\text { bmartin@wpgate.glo.state.tx.us } \\
\text { Texas General Land Office } \\
\text { Norman L. Guinasso, Jr. } \\
\text { F.J. Kelly } \\
\text { Texas A\&M University }\end{array}$ \\
\hline $\begin{array}{l}\text { Deployment and analysis of Argos tracked } \\
\text { surface drifters }\end{array}$ & $\begin{array}{l}\text { Surface trajectories of drifters deployed in } \\
\text { regions of shelf edge exchange and } \\
\text { Yucatan Current formation. }\end{array}$ & $\begin{array}{l}\text { Pearn Peter Niiler } \\
\text { pniiler@ucsd.edu } \\
\text { Carter Ohlmann } \\
\text { cohlmann@ucsd.edu } \\
\text { Scripps Institution of Oceanography } \\
\text { Henry J. White } \\
\text { hwhite@technocean.com } \\
\text { Technocean Inc., Cape Coral, FL }\end{array}$ \\
\hline $\begin{array}{l}\text { Development and testing of sea surface } \\
\text { altimeter buoy using global positioning sys- } \\
\text { tem (GPS) satellites }\end{array}$ & $\begin{array}{l}\text { Construction, design and calibration of } \\
\text { prototype GPS buoys for use in future } \\
\text { experiments } \\
\text { http://geodesy.eng.ohio-state.edu/GOM.html }\end{array}$ & $\begin{array}{l}\text { Michael R. Parke } \\
\text { mparke@geodesy.egn.ohio-state.edu } \\
\text { C.K. Shum } \\
\text { ckshum@osu.edu } \\
\text { Ohio State University }\end{array}$ \\
\hline $\begin{array}{l}\text { Circulation nowcasts and forecasts of } \\
\text { coastal regions using the Princeton } \\
\text { Dynalysis Ocean Model (PDOM) }\end{array}$ & $\begin{array}{l}\text { Forty-eight hour forecasts produced twice } \\
\text { daily based on ETA wind forecasts and river } \\
\text { runoff data } \\
\text { http://www.dynalysis.com }\end{array}$ & $\begin{array}{l}\text { Richard C. Patchen } \\
\text { H. James Herring } \\
\text { mail@dynalysis.com } \\
\text { Dynalysis of Princeton }\end{array}$ \\
\hline
\end{tabular}




\begin{tabular}{|c|c|c|}
\hline Task & Result & Principal Investigator \\
\hline $\begin{array}{l}\text { Circulation modelling with data assimilation } \\
\text { from satellite altimetry and AVHRR SST sea } \\
\text { surface temperature }\end{array}$ & $\begin{array}{l}\text { Basin-wide circulation calculations assimi- } \\
\text { lating NRL MODAS temperature and salinity } \\
\text { fields } \\
\text { http://www.dynalysis.com }\end{array}$ & $\begin{array}{l}\text { Richard C. Patchen } \\
\text { H. James Herring } \\
\text { mail@dynalysis.com } \\
\text { Dynalysis of Princeton }\end{array}$ \\
\hline $\begin{array}{l}\text { Tidal analysis with emphasis on coastal } \\
\text { regions of the Gulf of Mexico }\end{array}$ & $\begin{array}{l}\text { Data base of } 37 \text { tidal constituents on } 1-2 \\
\text { km finite element grid in coastal regions }\end{array}$ & $\begin{array}{l}\text { Norman W. Scheffner } \\
\text { n.scheffner@cerc.wes.army.mil } \\
\text { Coastal and Hydraulics Laboratory-WES }\end{array}$ \\
\hline $\begin{array}{l}\text { Generated merger scatterometer wind fields } \\
\text { from NSCAT and ERS-2 to use as surface } \\
\text { boundary conditions for circulation model }\end{array}$ & $\begin{array}{l}\text { Produce time series of composite wind } \\
\text { velocity, stress, and curl fields } \\
\text { http://geodesy.eng.ohio-state.edu }\end{array}$ & $\begin{array}{l}\text { C.K. Shum } \\
\text { ckshum@osu.edu } \\
\text { Michael E. Parke } \\
\text { mparke@ocean.eng.ohio-state.edu } \\
\text { Ohio State University }\end{array}$ \\
\hline $\begin{array}{l}\text { Reduction of satellite altimetry uncertainty } \\
\text { due to geographically correlated orbit errors, } \\
\text { and also using geophysical instrument } \\
\text { corrections }\end{array}$ & $\begin{array}{l}\text { Gridded SSH anomaly fields with associated } \\
\text { error assessments } \\
\text { http://geodesy.eng.ohio-state.edu }\end{array}$ & $\begin{array}{l}\text { C.K. Shum } \\
\text { ckshum@osu.edu } \\
\text { Michael E. Parke } \\
\text { mparke@ocean.eng.ohio-state.edu } \\
\text { Ohio State University }\end{array}$ \\
\hline $\begin{array}{l}\text { Analysis of hydrographic surveys on } \\
\text { satellite track transects }\end{array}$ & $\begin{array}{l}\text { Analysis of density structure, dynamic heights } \\
\text { and cross track geostrophic velocity for } \\
\text { altimeter calibration and geoid determination } \\
\text { http://gulf.ocean.fsu.edu/ sturges } \\
\text { /Gomoms }\end{array}$ & $\begin{array}{l}\text { Wilton Sturges, III } \\
\text { sturges@ocean.fsu.edu } \\
\text { Florida State University }\end{array}$ \\
\hline $\begin{array}{l}\text { Analysis of PALACE data to refine } \\
\text { estimates of deepwater and surface currents }\end{array}$ & $\begin{array}{l}\text { Near-realtime reports of } 900 \mathrm{~m} \text { float trajec- } \\
\text { tories on Web } \\
\text { http://gulf.ocean.ocean.fsu.edu/ natassa/ } \\
\text { GoMoms/methodology.html }\end{array}$ & $\begin{array}{l}\text { Georges L. Weatherly } \\
\text { weatherly@ocean.fsu.edu } \\
\text { Florida State University }\end{array}$ \\
\hline $\begin{array}{l}\text { Design of Profiling Lagrangian Circulation } \\
\text { Explorer PALACE subsurface floats and } \\
\text { raw data processing }\end{array}$ & $\begin{array}{l}\text { Measurements of } 900 \mathrm{~m} \text { currents and } \\
\text { temperature profiles processed in near- real } \\
\text { time and reported on the web } \\
\text { http://www.cape.com/ profiles }\end{array}$ & $\begin{array}{l}\text { Douglas Webb } \\
\text { dwebb@webbresearch.com } \\
\text { Webb Research Corporation }\end{array}$ \\
\hline
\end{tabular}

height anomaly obtained from satellite altimetry is critical, since it is used to determine the subsurface density structure used in data assimilation in circulation modeling. Therefore, one major initiative of the OMS program was to refine determination of the surface height and of the geoid, both of which are necessary to obtain the anomaly. During a previous study of Gulf of Mexico modeling sponsored by the Minerals Management Service, the Princeton-Dynalysis Ocean Model (PDOM) simulations of the circulation on the continental shelf were performed, Herring et al. (1999). The resulting surface current fields are shown to represent more than $60 \%$ of the variance in comparison with ARGOS tracked drifters. However, on the slope and in the deep Gulf the circulation is dominated by the Loop Current and associated warm and cold core eddies. This necessitates that the model hydrographic fields must be initialized with the Loop and eddy signatures in order to represent the location and strength of these currents accurately. The practical method of obtaining information on the location and strength of these structures in near-realtime is from satellite altimetry. The density structure of the water column is, then, inferred from the surface height anomaly, using the Modular
Ocean Data Assimilation System (MODAS) developed by the Naval Research Laboratory (Carnes and Mitchell, 1990; Carnes et al., 1994), to estimate the structure with correlation functions based on regional hydrography. The three dimensional hydrographic field is also adjusted to reflect the remotely measured sea surface temperature distribution.

To assure the most accurate determination of the sea surface height (SSH) from the TOPEX satellite altimetry, ground truth was obtained from a combination of shipboard and airborne sampling of the currents and hydrographic structure. Two major cruises were carried out aboard the $R / V$ Gyre, one in the Gulf of Mexico and one in the Cayman Sea. The latter, a collaborative United States-Mexican-Cuban cruise, was conducted during October 1999, contemporaneous with the Deepstar-CICESE measurements in the Yucatan Strait. Conductivity-temperature versus depth (CTD) and expendable bathythermograph (XBT) measurements of the density structure of the profile were made during the satellite overflight to calibrate the SSH from the altimetry. Aircraft deployed XBTs were used to make additional measurements of the temperature structure along a number of satellite tracks including the 
Cayman Sea Transect. The hydrographic data have been analyzed to determine the dynamic heights and height uncertainties. The dynamic heights in turn have been compared with the altimetry, as shown for example in Figure 1, and also to estimate cross-track velocities for comparison with the ARGOS drifters. In addition to providing near-realtime Gulf of Mexico altimetry products on their web site, the satellite altimetry group at Colorado Center for Astrodynamics Research (CCAR) provides data from these transects. whose cause and even existence is not well documented. Therefore this region was selected for more study. Surface current fields were determined using four deployments where 20 ARGOS-tracked drifters were released in the vicinity of semi-permanent warm and cold eddies impinging upon the continental boundary as determined from satellite altimetry supplied by CCAR. The comparison of current velocities from the drifters with geostrophic currents computed from altimeter data, as shown in Figure 2, indicate that there

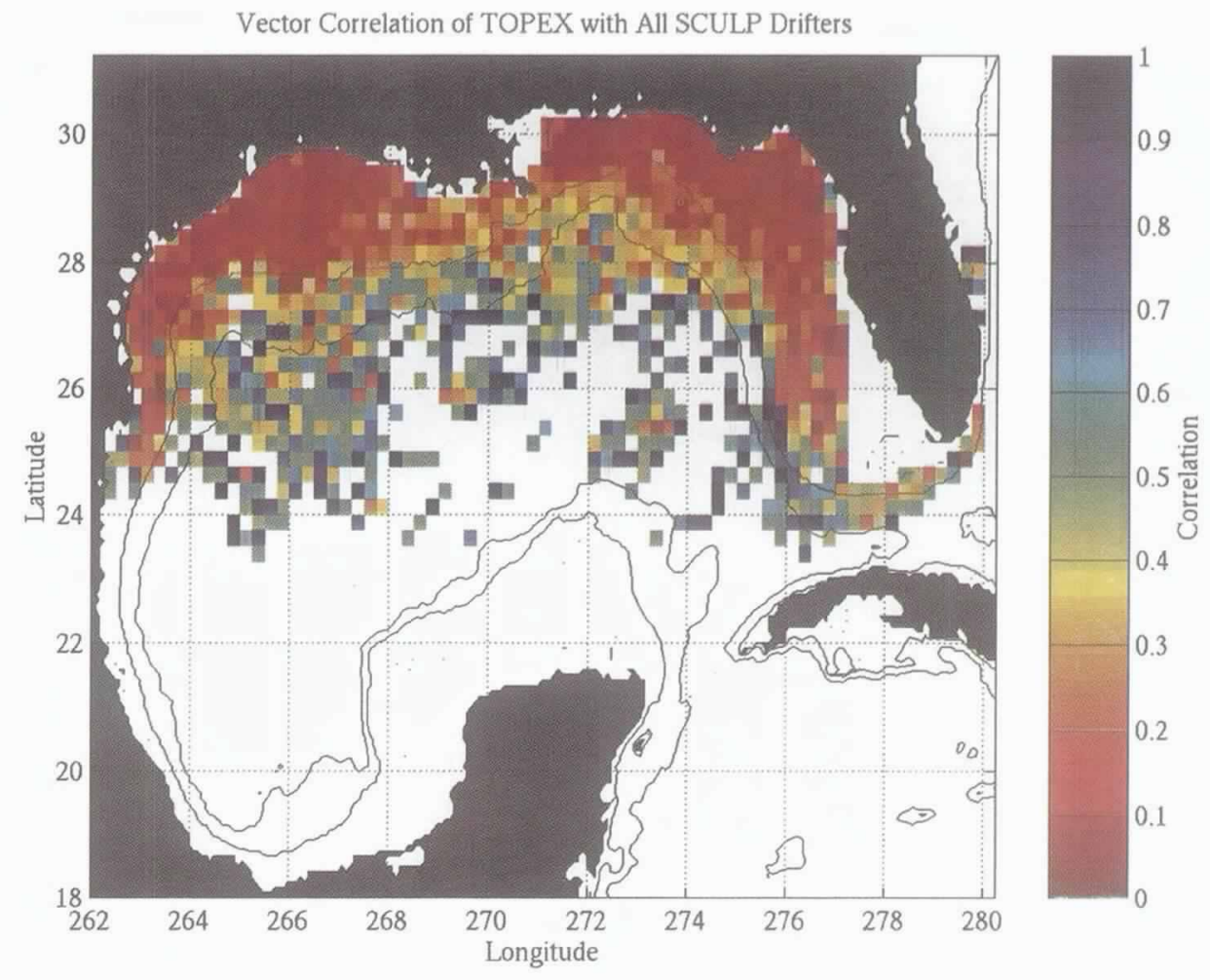

Figure 2: Map of vector component correlation coefficient between geostrophic velocities computed from blended TOPEX/ERS sea surface height anomalies plus 10year climatological model mean sea surface and daily averaged SCULP drifter velocities. The 200 and 1500 meter isobaths are shown.
Another major research initiative was to gain improved understanding of circulation dynamics in the shelf edge and shelf slope regions. For water depths greater than 200 meters comparisons between the ARGOS drifters and geostrophic velocities from the satellite altimeter are shown by Olhmann et al. (2000) to account for more than half of the variance of the surface currents. Similarly it has been shown, as described above, that the PDOM driven with realistic synoptic wind fields produces very good results on the shelf. Evidently, then, it is the dynamics of the shelf-break region which require further attention. From satellite AVHRR surface temperature images and current meter data (Nowlin et al., 1998), it is evident that considerable shelf edge exchange takes place in the presence of both warm and cold core eddies. Furthermore, both the observational data (Hamilton, 1992) and earlier PDOM results (Herring et al., 1999) indicate persistent alongslope currents in the range of $10 \mathrm{~cm} / \mathrm{sec}$ and, for periods of a month or more sometimes 3 times as large, is little correlation in water depths of less than $50 \mathrm{~m}$; between 50 and $200 \mathrm{~m}$ the correlation improves, but the drifters mostly follow isobaths rather than dynamic height contours; and in deeper water the drifters agree well with geostrophic currents from altimeter data.

Temperature Profiling Lagrangian Circulation Explorer (PALACE) subsurface floats ballasted for 850 meters depth to address the question of the current distribution in deeper water. These PALACE floats ascend to the surface every 7 days, measuring the temperature profile as they rise and then transmit the data by ARGOS satellite. After twelve hours of data transmission, the float descends again and continues following the currents at 850 meters. The float tracks, which indicate the 850 meter currents, and the vertical temperature profiles are posted on the Internet in near realtime. Also considerable analysis has been performed to refine the accuracy of the deep current vectors by removing the effects of the surface currents and vertical profile currents. A plot of the currents at 900 meter depth as determined from 


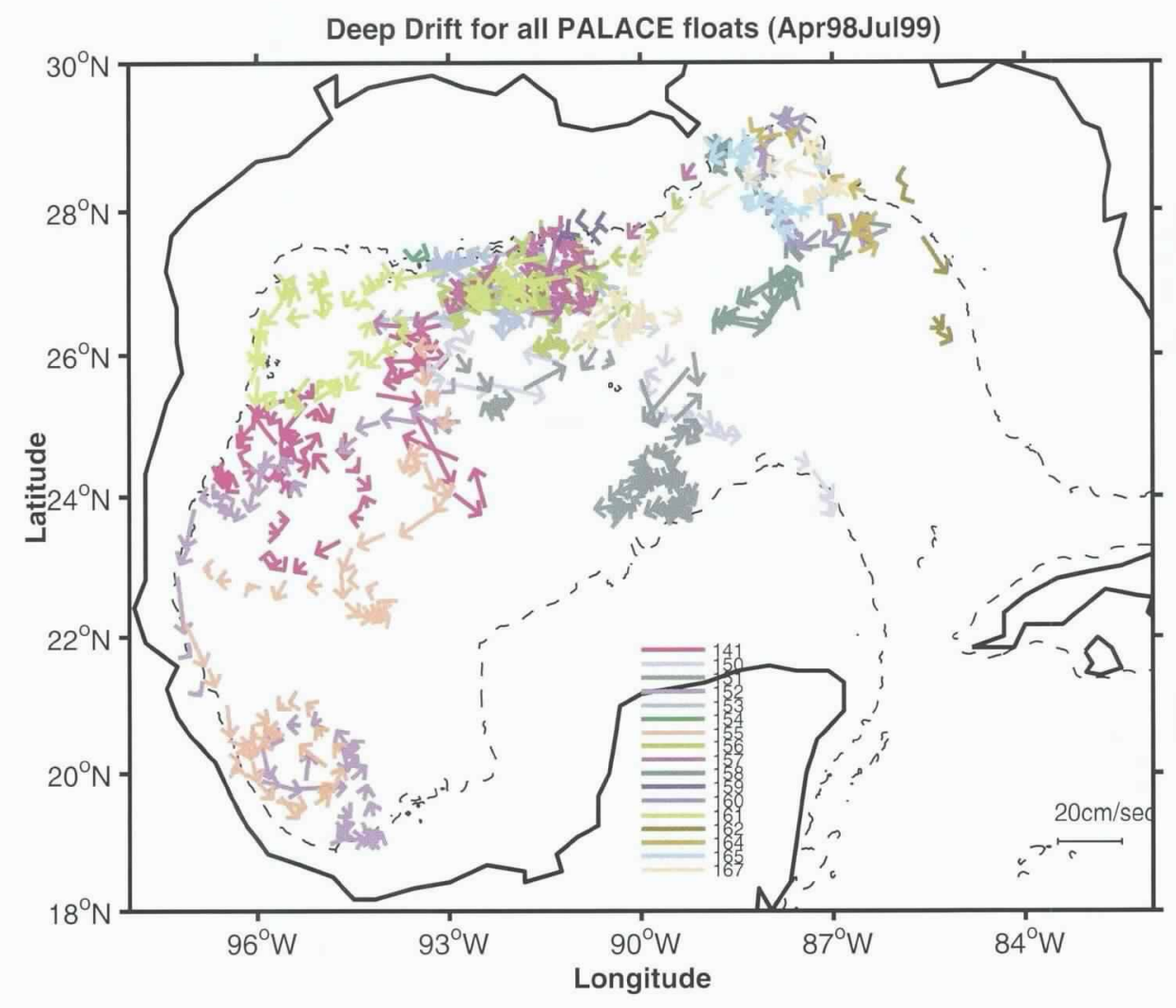

Figure 3: The deep displacement vectors for all the PALACE floats. The $1000 \mathrm{~m}$ isobath is indicated. The color bars identify the individual float tracks. the PALACE floats is shown in Figure 3.

Based in part on the results obtained from these experiments, a fully-automated realtime nowcast/forecast of the Gulf of Mexico circulation on the continental shelf has been operational and reporting results on the Internet since September of 1998. The system automatically seeks and retrieves National Weather Service $29 \mathrm{~km}$ ETA meteorological forecasts on the Internet. The system interrogates USGS offices in five states over the Internet to obtain realtime river flow data for 25 of the major rivers. Beginning with conditions from the last nowcast calculation, the model is driven with realtime data, with assimilation of MODAS hydrographic structure and the resulting simulations are archived. As an example of the results, the simulated surface elevation for April 16, 1998 shown in Figure 4, may be compared with an SSH field prepared independently at CCAR in Figure 5. The system will automatically refresh the OMS web site and is designed to transmit the results to a data server at NAVO in Stennis for distribution and archiving.

Finally, the incentive for the Cayman sea cruise and the interest in the collaborative effort to obtain the Yucatan Straits measurements is the result of the requirement to make longer term forecasts in the Gulf of Mexico. It has long been observed that the timing of the dominant Gulf event, the shedding of an eddy by the Loop current, remains a mystery. Although statistical boundaries can be placed on eddy shedding
(Vukovich, 1995), the standard deviation is large, and the results are not particularly useful. Furthermore, since the influence of the location of the Loop and the motion of the eddy which is shed have a profound influence on the circulation throughout the Gulf, some ability to anticipate or even to simulate the behavior of the Loop and eddy shedding in a deterministic sense would be extremely valuable. There is every reason to expect that the behavior of the Loop is at least correlated with the temporal and spatial variation of transport through the Yucatan Straight and a study of the relationship between them should be a starting point. In addition to the natural incentive to understand Loop dynamics for their own sake, there is the important further motivation that, in order to perform the nowcast/forecast, some near-realtime alias for the Yucatan transport distribution is essential. Remote sensing holds the most promise for timely transport data availability and, in the spirit of the satellite altimeter surveys performed in the Gulf proper, the choice of a Yucatan Straight alias is the ascending TOPEX track that crosses the Carribean Sea from Honduras to Cuba and referred to here as the Cayman Sea Transect. The next step is to analyze the data from the Cayman Sea Transect and correlate it with the measurements in the Yucatan Straits and the Loop behavior to verify the suitability of the Cayman Sea altimetry as a model inlet boundary condition. The Yucatan Straits measurements are scheduled to be completed in the spring of 2001. 


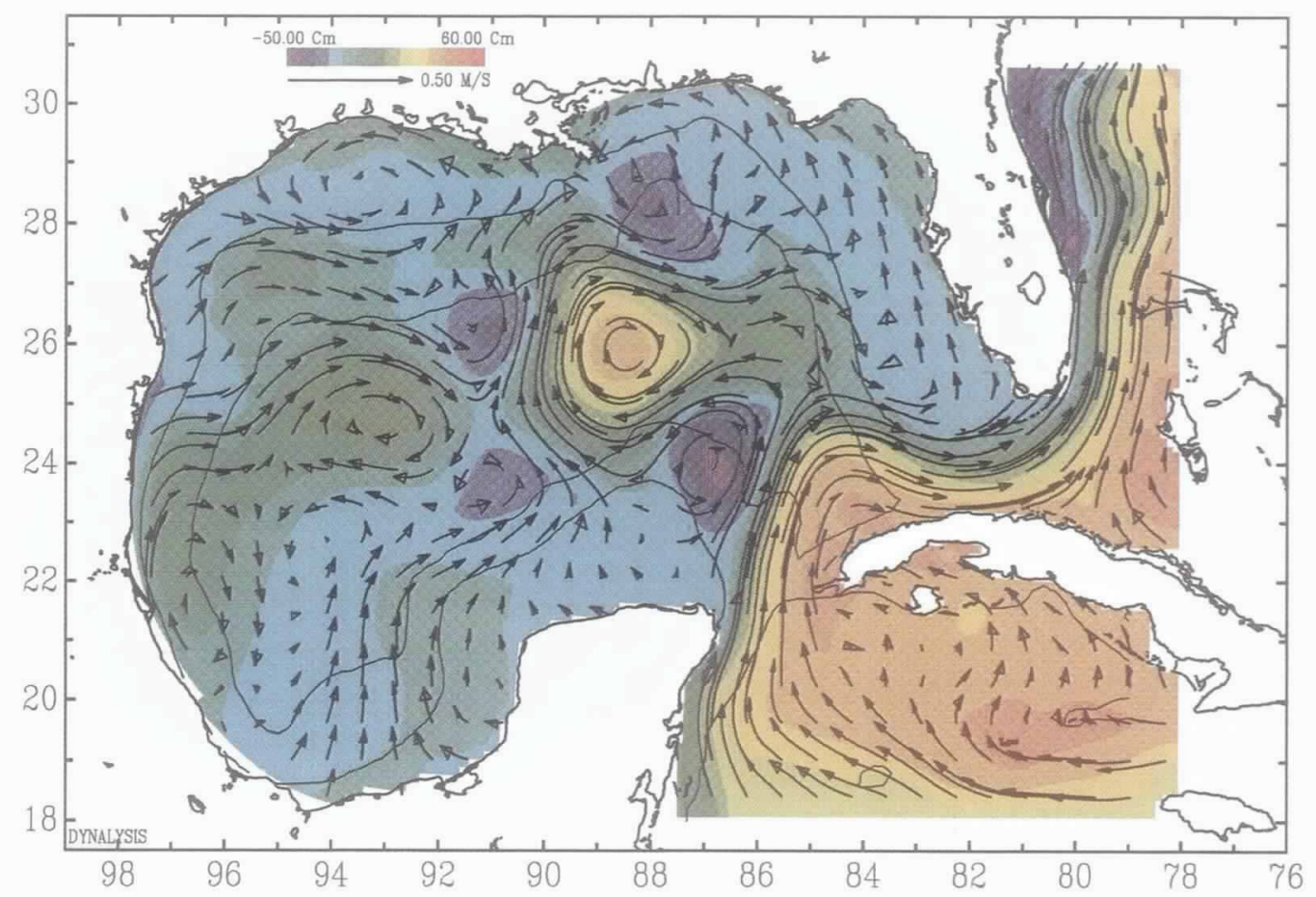

Figure 4: Surface elevation field for April 16, 1998 from the PDOM Nowcast/Forecast model which is assimilating MODAS hydrographic fields from early April 1998.

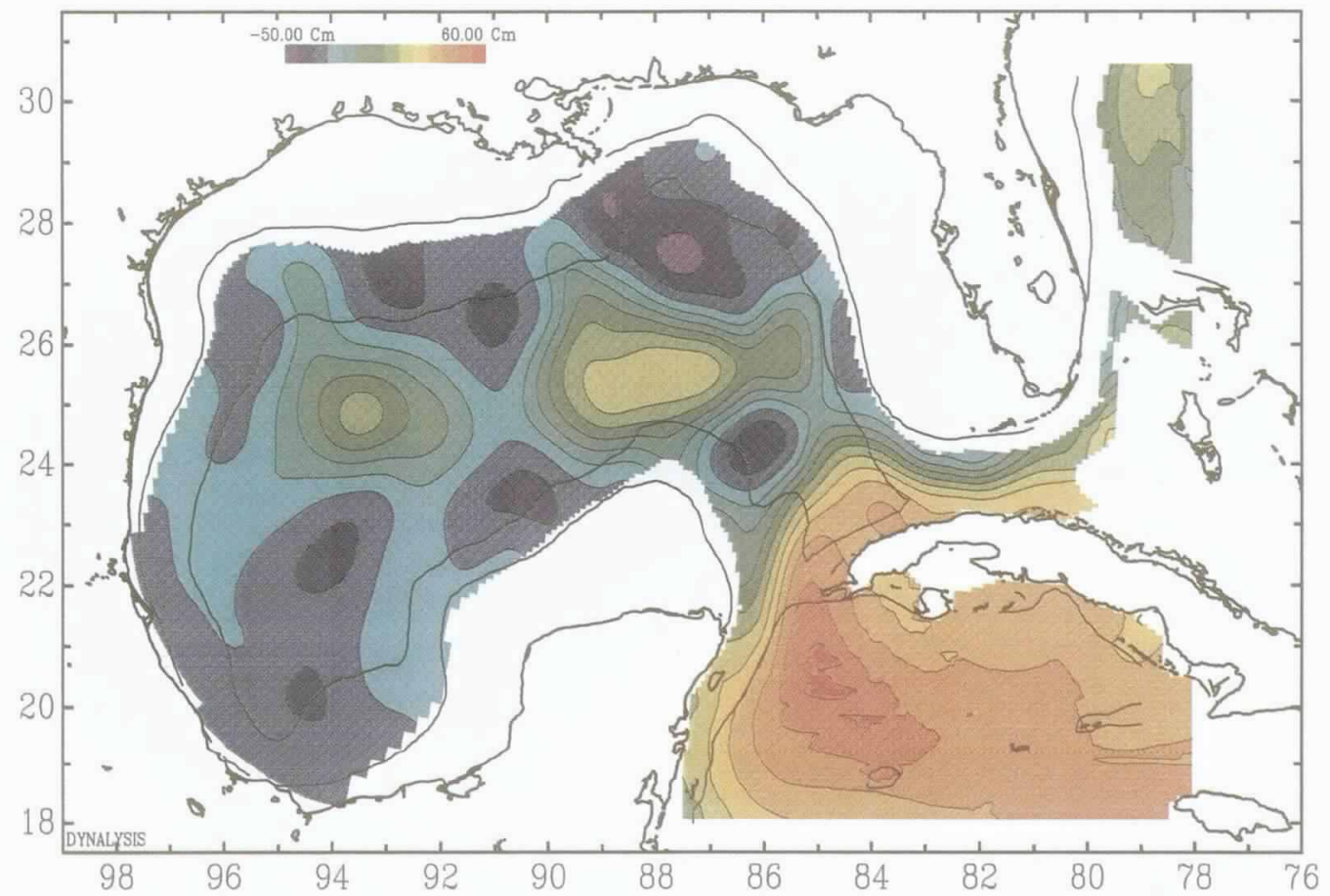

Figure 5: Sea surface height for April 16, 1998 field from CCAR produced from composite TOPEX/ERS-2 altimeter data. 


\section{Conclusion}

The OMS program originally consisted of a group of approximately 20 participants drawn from academia, federal and state government and industry. Building on this foundation, following the guidelines of the NOPP announcement, the OMS program has successfully included and involved more than twice that number of research oceanographers in a considerably expanded level of effort to accomplish the objectives of the study. The additional collaborators, once again, included representatives of academia, government and industry but now the representation is international, including scientists from Mexico, and Cuba. Furthermore, the observational program had an international component since measurements were made in the waters of each of these countries. This extended collaboration has made the OMS and the associated studies much more productive and, in addition, many of the participants have established scientific relationships which will facilitate productivity in future scientific programs.

From the start of the OMS program, the stated intention was to make all data available to the oceanographic community as soon as possible, and in many cases, this meant in near-real time. The data available on the web sites in Table 1 are being used by other research groups. Obvious applications for the observational data are to augment an existing data set or to provide means of performing a skill assessment of a model simulation. The result is that the oceanographic research community has observational data and computational results available in near-real time rather than waiting years for a publication.

\section{REFERENCES}

Carnes, M.R. and J.L. Mitchell, 1990: Synthetic temperature profiles from Geosat altimetry: comparison with air dropped expendable bathythermograph profiles. J. Geophys. Res., 95(C10): 17979-17992.

Carnes, M.R., W.J. Teague and H.L. Mitchell, 1994: Inference of subsurface thermohaline structure from fields measurable by satellite. J. Atmos and Oc. Tech., 11(2).

Hamilton, P., 1992: Lower continental slope cyclonic eddies in the central Gulf of Mexico. J. Geopllys. Res., 97(C2): 2185-2200.
Herring, H.J., M. Inoue, G.L. Mellor, C.N.K. Mooers, P.P. Niiler, L.-Y. Oey, R.C. Patchen, F.M. Vukovich, and W.J. Wiseman, Jr., 1999: Coastal Ocean Modeling Program for the Gulf of Mexico, Final Report. U. S. Department of the Interior, Minerals Management Service, $539 \mathrm{pp}$.

Nowlin, W.D., Jr., 1997: U.S. ocean science needs for modeling and data synthesis: status of a community assessment. Oceanographly, 10(3), 135-140.

Nowlin, W.D., Jr., A.E. Jochens, R.O. Reid, and S.F. DiMarco, 1998: Texas-Louisiana Shelf Circulation and Transport Processes Study. OCS study MMS-98-0035 Department of the Interior, Minerals Management Service: $448 \mathrm{pp}$.

Ohlmann, J.C., P.P. Niiler, C.A. Fox and R.R. Leben,. Eddy energy and shelf interactions. J. Geoplyys. Res., in press.

Vukovich, F.M., 1995: An updated evaluation of the Loop Current's eddy-shedding frequency. J. Geoplyss. Res., 100(C5): 8561-8569.

\section{AFFILIATIONS}

John P. Blaha, Naval Oceanographic Office, Stennis Space Center, Mississippi USA; George H. Born, Robert R. Leben, University of Colorado, Boulder, Colorado USA; Norman L. Guinasso, Jr., F.J. Kelly, Texas A\&M University, Corpus Christi, Texas USA; H. James Herring, Richard C. Patchen, Dynalysis of Princeton, Princeton, New Jersey USA; Gregg A. waiting years for a publication. Jacobs, Naval Research Laboratory,
Stennis Space Center, Mississippi waiting years for a publication. Jacobs, Naval Research Laboratory,
Stennis Space Center, Mississippi Austin, Texas USA; George L. Mellor, Princeton University, Princeton, New Jersey USA; Pearn Peter Niiler, Carter Ohlmann, Scripps Institution of Oceanography, LaJolla, California USA; C. K. Shum, Michael E. Parke, Ohio State University, Columbus, Ohio USA; Kennth Schaudt, Marathon Oil Company, Houston, Texas USA; Norman W. Scheffner, Waterways Experiment Station, Vicksburg, Mississippi USA; Wilton Sturges, III, Florida State University, Tallahassee, Florida USA; Georges L. Weatherly, Florida State University, Tallahassee, Florida USA; Douglas Webb, Webb Research Corporation, East Falmouth, Massachusetts USA; Henry J. White, Technocean, Inc., Cape Coral, Florida USA 